\title{
Emitter and tourist destination in Romania
}

Authors' Contribution: A Study Design

B Data Collection

C Statistical Analysis

D Data Interpretation

E Manuscript Preparation

F Literature Search

G Funds Collection

\author{
Grigore Vasile Herman ${ }^{1 A D E F}$, Dorina Camelia llieș ${ }^{1}$ ADE, Olivier Dehoorne ${ }^{2}$ ADE, \\ Alexandru Ilies ${ }^{1}$ ADE, Alphonse Sambou ${ }^{3}$ DF, Tudor Caciora ${ }^{4}$ BC, \\ Mamadou Diombera ${ }^{3}$ DF, Anamaria Lăzuran ${ }^{4}$ BC \\ ${ }^{1}$ Department of Geography, Tourism and Territorial Planning, \\ University of Oradea, Oradea, Romania \\ ${ }^{2}$ Department of Geography, University of Antilles, Pointe-á-Pitre, Reunion \\ ${ }^{3}$ Training and Research Unit of Economic and Social Science, Department of Tourism, \\ University of Ziguinchor Assane Seck, Ziguinchor, Senegal \\ ${ }^{4}$ Doctoral School in Geography, University of Oradea, Oradea, Romania
}

\section{abstract}

Background: The need to identify, analyze and establish relationships between destinations and tourist emission, as terminus points between which the tourist circulation takes place, arises from the structural and functional complexity of tourism, on the one hand, and from its unprecedented expansion, on the other hand.

Material and methods:

Within the present study, which concerned Romania as a tourist destination, a number of specific, determinative indicators for the emission areas and the tourist destinations were identified and analyzed.

Results: The obtained results focused on the analysis of: capacity, hierarchy, spatial distribution and establishment of relations between tourist emission / reception centers. They pointed out that Bucharest is the most important center of emission and tourist destination, followed by big urban centers of Constanța, Brasov, Mangalia, Cluj, Sibiu, Iași, etc., with some oscillations in what supposes their capacity of emission respectively tourist reception.

Conclusions: The spatial distribution of the tourist emission-reception centers at the level of Romania is a discontinuous, individualized nuclei of utmost importance (the mountain area, the Black Sea coast and the Bucharest area) and the poor areas in infrastructure and tourist objectives, which determines a low flow of tourists.

Key words: tourist emission, touristic destination, tourist indicators, Romania.

\section{article details}

Article statistics: Word count: 6,592; Tables: 0; Figures: 11; References: 50

Received: June 2020; Accepted: August 2020; Published: November 2020

Full-text PDF: http://www.balticsportscience.com

Copyright @ Gdansk University of Physical Education and Sport, Poland

Indexation: Celdes, Clarivate Analytics Emerging Sources Citation Index (ESCI), CNKI Scholar (China National Knowledge Infrastructure), CNPIEC, De Gruyter - IBR (International Bibliography of Reviews of Scholarly Literature in the Humanities and Social Sciences), De Gruyter - IBZ (International Bibliography of Periodical Literature in the Humanities and Social Sciences), DOAJ, EBSCO - Central \& Eastern European Academic Source, EBSCO - SPORTDiscus, EBSCO Discovery Service, Google Scholar, Index Copernicus, J-Gate, Naviga (Softweco, Primo Central (ExLibris), ProQuest - Family Health, ProQuest - Health \& Medical Complete, ProQuest - Illustrata: Health Sciences, ProQuest - Nursing \& Allied Health Source, Summon (Serials Solutions/ProQuest, TDOne (TDNet), Ulrich's Periodicals Directory/ulrichsweb, WorldCat (OCLC)

Funding: This research received no specific grant from any funding agency in the public, commercial, or not-for-profit sectors.

Conflict of interests:

Corresponding author:

Open Access License:
Authors have declared that no competing interest exists.

Grigore Vasile Herman, Faculty of Geography, Tourism and Sport University of Oradea 1st University Street, 410 087 Oradea: Romaniał e-mail: grigoreherman@yahoo.com.

This is an open access article distributed under the terms of the Creative Commons Attribution-Non-Commercial-NoDerivatives 4.0 International (https://creativecommons.org/licenses/by-nc-nd/4.0/), which permits use, distribution and reproduction in any medium, provided the original work is properly cited, the use is non-commercial and is otherwise in compliance with the license. 


\section{INTRODUCTION}

One of the fundamental features which define man as a species and structural part of the environment is movement (mobility). Throughout the history of humanity, man and the human communities have been in continuous mobility determined by a series of motivational internal factors (covering the basic food supply, water, shelter, etc.) and external factors (climate changes, geo-political conflicts, etc.). In this context, in the past, pilgrimages to holy places and sportive and cultural exhibitions have generated temporary migratory flows between a region of origin (emitter) and one of destination (receiver) [1-3].

In the last period, in the context of the social-economic development imposed by urbanization, industrialization and scientific and technical progress, the human society in general and man in particular have experienced a new type of mobility, namely migration for tourism purposes. The analysis of literature regarding the concept of "tourism" highlights the existence of the movement of tourists from one place to another, from a daily space to a tourist one, especially designed to meet their needs [4-11].

From the comparative analysis of "migration" and "tourism", it is clear that both concepts denote a form of mobility specific to man [7]. Therefore, tourism represents a form of migration realized by temporary and repeated change of residence for the purpose of leisure [5, 6, 12]. The analysis of literature on the relationship and migration is quite rich, addressing a series of issues: labor migration, entrepreneurial migration [7, 13], retirement migration [7, 9, 14-16], the socio-economic and ecological changes at the spatial and temporal level as a result of the mobility of population $[7,17,18]$, the typology and causes of tourist mobility [7, 8, 19], etc.

Therefore, we can state that tourist mobility involves the movement in time and space, from point A (the area of emitter) to point B (the area of destination), respectively from a T0 to Tx moment, of the all objects, processes and tourist facts. The longer the distance, the higher the costs will be. This is reflected by the time and the energy required to perform the mobility. If time is a relative resource, the necessary energy is reflected in the form of costs. Costs take a multitude of forms, starting with those needed to build the infrastructure and ending with environmental ones.

Tourism is one of the most dynamic branches of economy at the global level [20], contributing to the sustainable development of local economies, with the implication in generating of new jobs, diversifying the economic structure of an area, increasing the living standard [21, 22]. Tourism also presents an important social and ecological component [23-25], stripped from the social involvement at all levels for the preservation, promotion and capitalization of tourism resources [26].

Romania is a country with a tourist vocation that benefits from a genuine and traditional rural space. The wealth and morphological variety (plains, hills, mountains), doubled by hydrographic (the Danube River, the Danube Delta, the Black Sea, numerous inland rivers, more than 4000 lakes and over 3000 springs) and flora and fauna, make the CarpathianDanubian-Pontic space a natural heritage with a strong character of uniqueness and specificity [27].

Romania's vocation on tourism does not derive only from the contribution of the extremely rich and attractive natural environment, but also from the Romanian people's active participation in the creation of a material and spiritual patrimony of a distinct originality. Thus, the edifices created by man (Roman castles, fortresses, fortifications, castles, palaces, monasteries, stone and wood churches) reflect the stages of development of this historical-geographic space, representing at the same time a multimillenary proof 
of the continuity and Christianity of the people [28-30]. Another anthropological tourist resource with a strong character of originality and specificity is the unaltered Romanian folk culture, represented by the ethnographic tourist heritage (ancestral traditions and customs) and human activities (pastoral festivals, fairs, pilgrimages, artistic festivals, etc.).

The degree of qualitative and quantitative diversification of tourism infrastructure is closely related to the attractiveness of tourist attractions and the number of tourists [31]. Thus, infrastructure and tourism demand are in a relationship of interconditioning, each stimulating and conditioning the appearance, development and evolution of the other. The quality and diversity of the tourist offer is reflected directly in the tourist circulation, in the shaping of the tourist flows, the emitter areas, and respectively the tourist destination. In this background, this study aims to identify, analyze and hierarchize Romanian tourist emitter and reception areas and of the relationships between the two spatial entities.

\section{MATERIAL AND METHODS}

Methodologically, the present study implied identification, analysis and hierarchy of Romania's emitter and reception areas (development region, county and locality) in order to establish the determinant relations between them. The identification, analysis and hierarchy of the tourist emitter areas implied the analysis of the number and share of the travel agencies from Romania, the localities where the travel agencies are based, the travel agencies per locality, the population per locality, whereas, the identification, analysis and hierarchy of the tourist destination areas implied the analysis of the number and share of tourist arrivals, localities of arrivals, tourist arrivals per locality, tourists' overnight stays, localities of tourists' overnight stays, tourists' overnight stays per locality, accommodation capacity in function, and the accommodation capacity in function per locality on the level of development regions, counties and emitter localities. Data obtained from the National Institute of Statistics and Ministry of Tourism [32, 33] were transposed to a pre-existent database (points, polygons) created in ArcGis 10.6. The spatial analysis of the data was done at the point (locality) and polygon (development region, county) in order to understand the spatial relationships between the emitter centers and tourist destinations [34-37].

\section{RESULTS}

\section{TOURIST DESTINATIONS FROM ROMANIA}

Over the years, tourist destinations have been analyzed in the literature from various points of view, including the tourist infrastructure [38-42], climatic characteristics and their implications in the shaping of tourist destinations [43], the perception of tourists [44, 45], the competitiveness of tourist destinations [46-49] and the structural and functional developments of tourist destinations [50].

In order to identify, analyze and hierarchize the tourist destinations in Romania, three defining indicators (tourist arrivals, tourist attractions and tourist accommodation capacity in function) were analyzed, at the level of development of a region, county and locality.

Over the time, these indicators experienced a similar evolutionary trend, defining three evolutionary permanent intervals: descending evolution in 1990-1994, stability in 19942008, ascending evolution in 2008-2017 (Figure 1). 


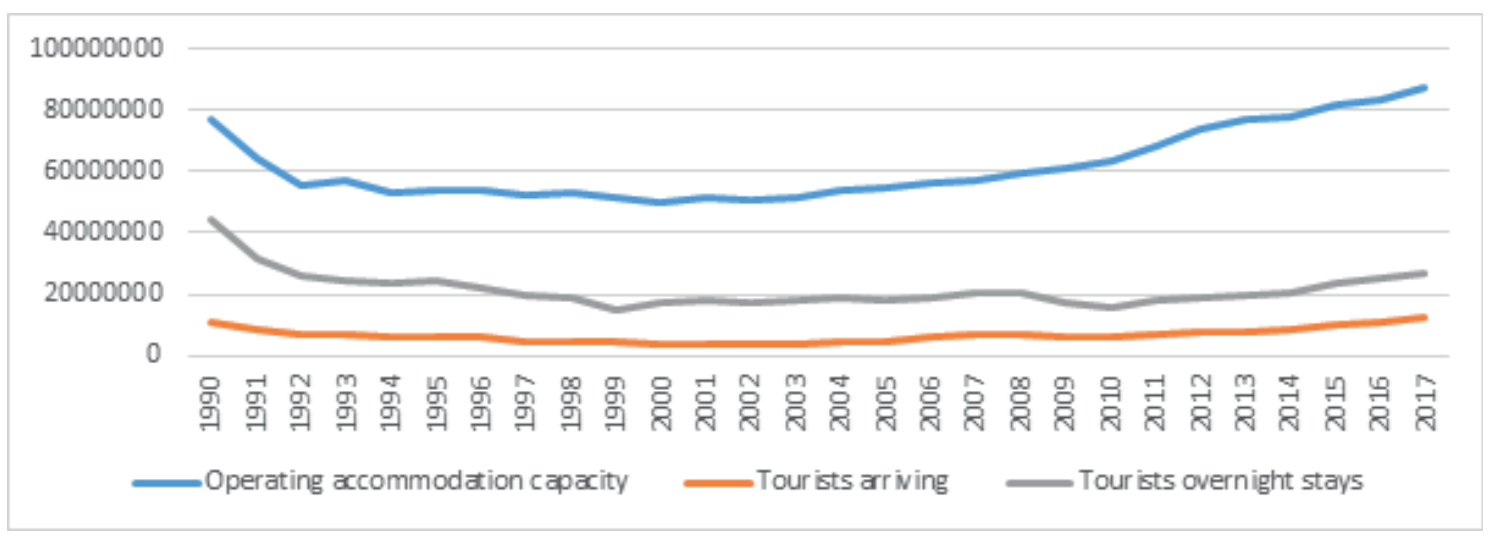

Fig. 1. Evolution of the operating accommodation capacity, tourists arriving and tourists overnight stays (Data sources: National Institute of Statistics)

Romania was defined in 2018 by 12,215,899 tourists arriving in 1,013 localities, 27,092,523 tourists overnight stays in 1,018 localities and an operating accommodation capacity of $87,655,760$ places in 1,024 localities which represents a $30.9 \%$ occupancy rate. The analysis of the share of the tourist reception volume on the development regions in Romania in 2018 revealed its predominance in the Central Region (23.2\%), followed in hierarchical order by the South-East Region (15.8\%), Bucharest (13.7\%), the North-West Region (12.8\%), the South Region (9.5\%), the North-East Region (9.4\%), the West Region (8.5\%) and the South-West Region (7.1\%).

The Central Region represents the most important tourist destination with $23.5 \%$ of all tourist arrivals in Romania (2,856,558 arrivals), distributed in 231 localities (23\% of the total number of the localities where arrivals were recorded), which represents an average value of 12,312 arrivals per locality; $21.8 \%$ of the total tourists' overnight stays in Romania $(5,897,215$ overnights), distributed in 232 localities (21.8\% of the total number of the localities were overnights were recorded), which represents an average value of 25,419 overnights per locality; $24.4 \%$ of the operating accommodation capacity in Romania $(21,431,280$ places), distributed in 232 localities ( $21.8 \%$ of the total number of the localities were overnights were recoded), which represents an average value of 25,419 overnights per locality.

The South-East development region represents the second region of tourist destinations concentrating: $12.7 \%$ of the total tourists' arrivals in Romania (1,551,463 arrivals), distributed in 51 localities (5\% of the total number of the localities were arrivals were recorded), which represents an average value of 30,420 arrivals per locality; $19.9 \%$ of the total tourists' overnight stays in Romania (5,398,498 overnights), distributed in 51 localities ( $5 \%$ of the total number of the localities were overnights were recoded), which represents an average value of 105,852 overnights per locality; $14.7 \%$ of the operating accommodation capacity in Romania $(12,856,343$ places), distributed in 51 localities ( $5 \%$ of the total number of the localities where accommodation places were recorded), which represents an average value of 252,085 places per locality.

The third place regarding the tourist destination is held by the Bucharest Region concentrating $18.2 \%$ of the total arrivals from Romania $(2,202,877$ arrivals), distributed in 14 localities (1.4\% of the total number of the localities were arrivals were recorded), which represents an average value of 157,348 arrivals per locality; $13.4 \%$ of the total overnights from Romania (3,600,639 overnights), distributed in 14 localities (1.5\% of the total number of the localities were overnights were recorded), which represents an average 
value of 257,188 overnights per locality; $9.5 \%$ of the operating accommodation capacity in Romania (8,354,594 places), distributed in 14 localities $(1.4 \%$ of the total number of the localities where accommodation places were recorded), which represents an average value of 596,756 places per locality.

On the opposite end, in the last place regarding the tourist destination, is the SouthWest Region, concentrating: $6.2 \%$ of the total arrivals from Romania (750,011 arrivals), distributed in 81 localities ( $8 \%$ of the total number of the localities where arrivals were recorded), which represents an average value of 9,259 arrivals per locality; $7.3 \%$ of the total tourists' overnight stays in Romania (1,973,344 overnights), distributed in 86 localities ( $8.4 \%$ of the total number of the localities were overnights were recoded), which represents an average value of 22,945 overnights per locality; $7.7 \%$ of the operating accommodation capacity in Romania $(6,759,795$ places), distributed in 89 localities $(8.7 \%$ of the total number of the localities where accommodation places were recorded), which represents an average value of 75,952 places per locality (Figure 2).

From the assessment of the share of the dispersion in the space of tourist reception capacity, the following situation appeared in a hierarchical order: the Central Region (22.8\%), followed by the North-West Region (18.9\%), the South Region (15.8\%), the NorthEast Region (15.4\%), the West Region (12.3\%), the South-West Region (8.4\%), the SouthEast Region (5\%) and Bucharest (1.4\%), whereas, from the analysis of the share of the tourist reception volume at the level of localities of the development regions, the situation is as follows: Bucharest (55.7\%), the South-East Region (18.4\%), the Central Region (6\%), the South-West Region (4.9\%), the West Region (4\%), the North-West Region (3.9\%), the South Region (3.6\%) and the North-East Region (3.5\%) (Figure 3).

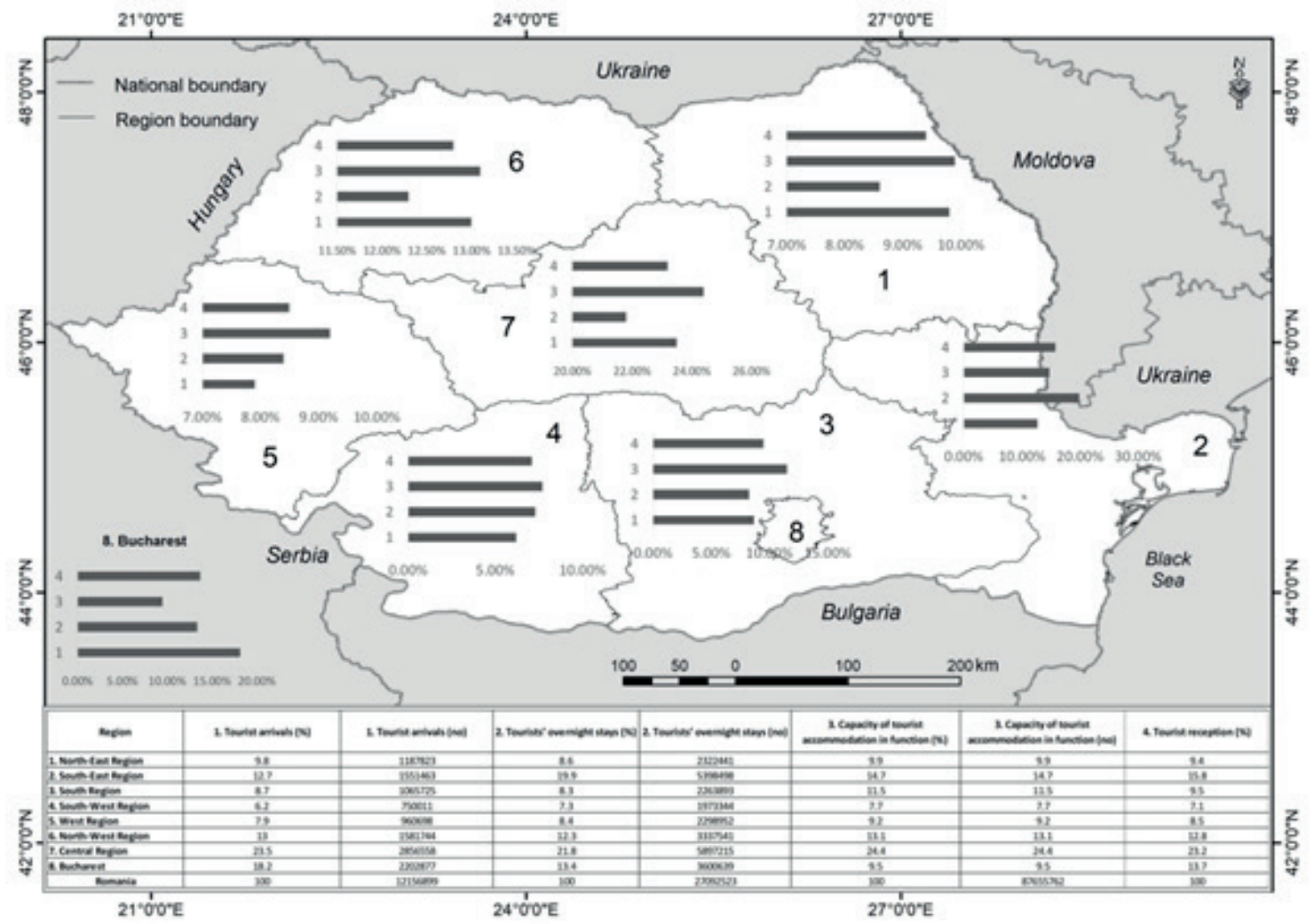

Fig. 2. Distribution of the share of the tourist reception volume at the level of development regions 


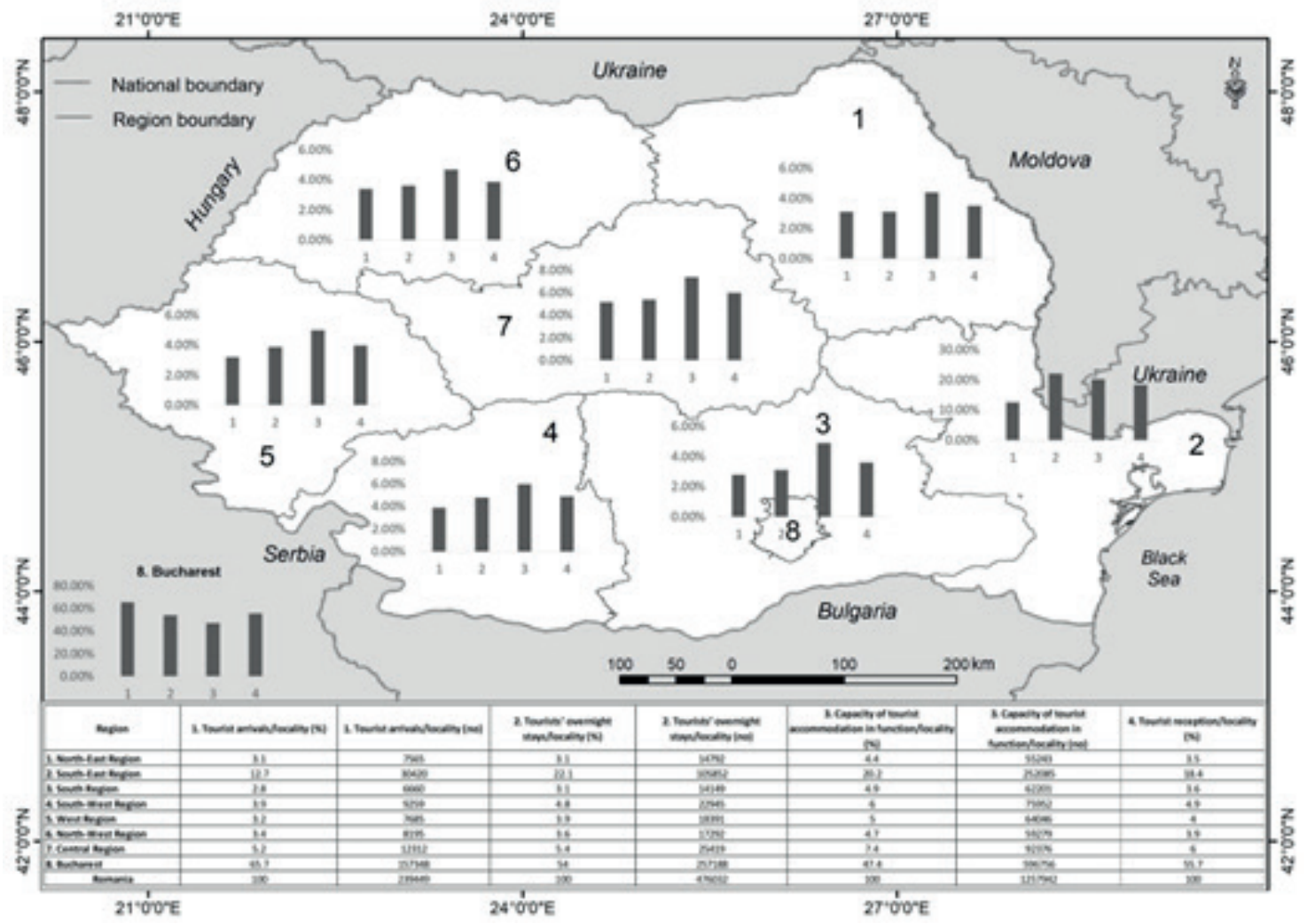

Fig. 3. Distribution of the share of the tourist reception volume relative to locality at the level of development regions

Data sources: National Institute of Statistics, 2019; Ministry of Tourism, 2019

The analysis of the share of the tourist arrivals at the level of development regions in Romania in 2018 revealed its predominance at the level of the Central Region (23,5\%), followed in a hierarchical order by Bucharest (18.2\%), the North-West Region (13\%), the South-East Region (12.7\%), the North-East Region (9.8\%), the South Region (8.7\%), the West Region (7.9\%), and the South-West Region (6.2\%) (Figure 2). Following the assessment of the spatial tourist arrivals dispersion at the level of development regions, the Central Region dominated (232 localities, 23\%), followed by the North-West Region (193 localities, 19\%), the South Region (160 localities, 15.8\%), the North-East Region (157 localities, 15.5\%), the West Region (125 localities, 12.3\%), the South-West Region (81 localities, 8\%), the South-East Region (51 localities, 5\%) and Bucharest (14 localities, $1.4 \%)$. The analysis of the share of the tourist arrivals per locality at level of development regions, shows that the Bucharest Region stands out (65.7\%, 157,348 tourist arrivals per locality), followed by the South-East Region (12.7\%, 30,420 tourist arrivals per locality), the Central Region (5.2\%, 12,312 tourist arrivals per locality), the South-West Region (3.9\%, 9,259 tourist arrivals per locality), the North-West Region (3.4\%, 8,195 tourist arrivals per locality), the West Region (3.2\%, 7,685 tourist arrivals per locality), the NorthEast Region (3.1\%, 7,565 tourist arrivals per locality) and the South Region (2.8\%, 6,660 tourist arrivals per locality) (Figure 3).

The analysis of the share of the tourists' overnight stays at the level of development regions in Romania revealed its predominance in the Central Region (21.8\%), followed by the South-East Region (19.9\%), Bucharest (13.4\%), the North-West Region (12.3\%), the North-East Region (8.6\%), the West Region (8.4\%), the South Region (8.3\%) and the South-West Region (8.2\%) (Figure 2). An assessment of the share of spatial dispersion of tourists' overnight stays in the development regions showed the highest level in the Central Region (232 localities, 22.7\%), followed by the North-West Region (193 localities, 
18.9\%), the South Region (160 localities, 15.8\%), the North-East Region (157 localities, $15.4 \%$ ), the West Region (125 localities, 12.3\%), the South-West Region (86 localities, 8.4\%), the South-East Region (51 localities, 5\%) and Bucharest (14 localities, 1.5\%). In the analysis of the share of the tourists' overnight stays per locality, Bucharest region stands out (54\%, 257,188 overnights per locality), followed by the South-East Region $(22.1 \%, 105,852$ overnights per locality), the Central Region (5.4\%, 25,419 overnights per locality), the South-West Region (4.8\%, 22,945 overnights per locality), the West Region (3.9\%, 18,391 overnights per locality), the North-West Region (3.6\%, 17,292 overnights per locality), the North-East Region (3.1\%, 14,792 overnights per locality) and the South Region (3.1\%, 14,149 overnights per locality) (Figure 3).

The analysis of the share of the volume of accommodation capacity in function at the level of development regions in Romania in 2018 revealed its predominance in the Central Region (24.4\%), followed by the South-East Region (14.7\%), the North-West Region (13.1\%), the South Region (11.5\%), the North-East Region (9.9\%), Bucharest (9.5\%), the West Region (9.2\%), the South-West Region (7.7\%) (Figure 2). An assessment of the share of spatial dispersion of the tourist accommodation capacity at the level of development regions revealed that the Central Region (232 localities, 22.6\%) has the highest degree of dispersion, followed by the North-West Region (193 localities, 18.8\%), the South Region (161 localities, 15.7\%), the North-East Region (158,localities, 15.4\%), the West Region (126 localities, 12.4\%), the South-West Region (89 localities, 8.7\%), the South-East Region (51 localities, 5\%) and Bucharest (14 localities, 1.4\%). The analysis of the share of the accommodation capacity in function per locality, the Bucharest region stands out $(47.4 \%$, 596,756 accommodation places), followed by the South-East Region (20.2\%, 252,085 accommodation places), the Central Region (7.4\%, 92,376 accommodation places), the South-West Region (6\%, 75,952 accommodation places), the West Region (5\%, 64,046 accommodation places), the North-West Region (4.9\%, 62,201 accommodation places), the North-East Region (4.7\%, 59,279 accommodation places) and the South Region $(4.4 \%$, 55,243 accommodation places) (Figure 3).

The analysis of the share of the tourist reception volume in counties in 2018 revealed the predominance of Constanța county (13.1\%), followed by Bucharest (12.6\%), Brașov (10.3\%), Prahova (4.5\%), Cluj (4.4\%), Bihor (4.2\%), Mureș (4\%), Vâlcea (3.9\%), Sibiu $(3,8 \%)$, Timiș (3.2\%), Suceava (3.1\%), Caraș-Severin $(2.1 \%)$ and Iași $(2.12 \%)$. In the last places regarding the share of the tourist reception volume were situated counties of Giurgiu $(0.25 \%)$, Calarași $(0.23 \%)$ and Teleorman $(0.1 \%)$. Constanța county represents the most important territorial unit as a tourist destination, concentrating $10.1 \%$ of the total arrivals from Romania (1,235,542 arrivals), distributed in 16 localities (1.57\% of the total number of the localities were arrivals were recorded), which represents an average value of 77,221 arrivals per locality; $17.4 \%$ of the total tourists' overnight stays in Romania $(4,729,186$ overnights), distributed in 16 localities (1.57\% of the total number of the localities were overnights were recorded), which represents an average value of 295,574 overnights per locality; $11.9 \%$ of the accommodation capacity in function in Romania (10,448,065 places), distributed in 16 localities $(1.57 \%$ of the total number of the localities were overnights were recorded), which represents an average value of 653,004 overnights per locality. Bucharest Municipality represents the second administrative unit ranking as a tourist destination, concentrating $16.8 \%$ of the total tourist arrivals in Romania (2,043,970 arrivals); $12.4 \%$ of the total tourists' overnights in Romania (3,360,245 overnights); $8.7 \%$ of the tourist accommodation capacity in function in Romania (7,626,518 places). The third place, in terms of tourist destination at the county level, is held by Brașov county concentrating $10.3 \%$ of the total arrivals in Romania $(1,260,742$ arrivals), distributed in 44 localities ( $4.3 \%$ of the total numbers of the localities were arrivals were recorded), which represents an average value of 28,653 arrivals per locality; $9.3 \%$ of the total tourists' overnight stays 
in Romania (2,531,053 overnights), distributed in 44 localities ( $4.3 \%$ of the total number of the localities were overnights were recorded), which represents an average value of 57,523 overnights per locality; $11.3 \%$ of the tourist accommodation capacity in function in Romania $(9,918,794$ places), distributed in 44 localities $(4.3 \%$ of the total number of the localities where there were accommodation places), which represents an average value of 225,427 accommodation places per locality. On the opposite end, in the last place in terms of tourist destination, Teleorman county is situated, concentrating $0.08 \%$ of the total arrivals in Romania (10,704 arrivals), distributed in 11 localities (1.08\% of the total number of the localities where arrivals were recorded), which represents an average value of 973 arrivals per locality; $0.06 \%$ of the total tourist overnight stays (18,695 overnight stays), distributed in 11 localities (1.08\% of the total number of the localities were overnight stays were recorded), which represents an average value of 1,699 overnights per locality; $0.2 \%$ of the accommodation capacity in function in Romania (225,083 places), distributed in 11 localities $(1.08 \%$ of the total number of the localities where accommodation places were recorded), which represents an average value of 20,462 accommodation places per locality (Figure 4). From the assessment of the spatial dispersion of tourist reception capacity, it followed that the highest share was held by the counties of (5.5\%), Maramures (4.6\%), Harghita (4.5\%), Alba (4.4\%) and Brașov (4.3\%), whilst on the opposite end there were counties of Calărași (0.4\%), Botoșani (0.3\%) and Bucharest Municipality (0.09\%). From the analysis of the share of the tourist reception capacity volume at the level of the localities of the counties it emerged that the highest share was held by the Bucharest Municipality (76.7\%), followed by Constanța (5.3\%), Brașov (1.5\%), Prahova (0.9\%), Vâlcea $(0.8 \%)$ and Bihor (0.7\%) counties (Figure 5).

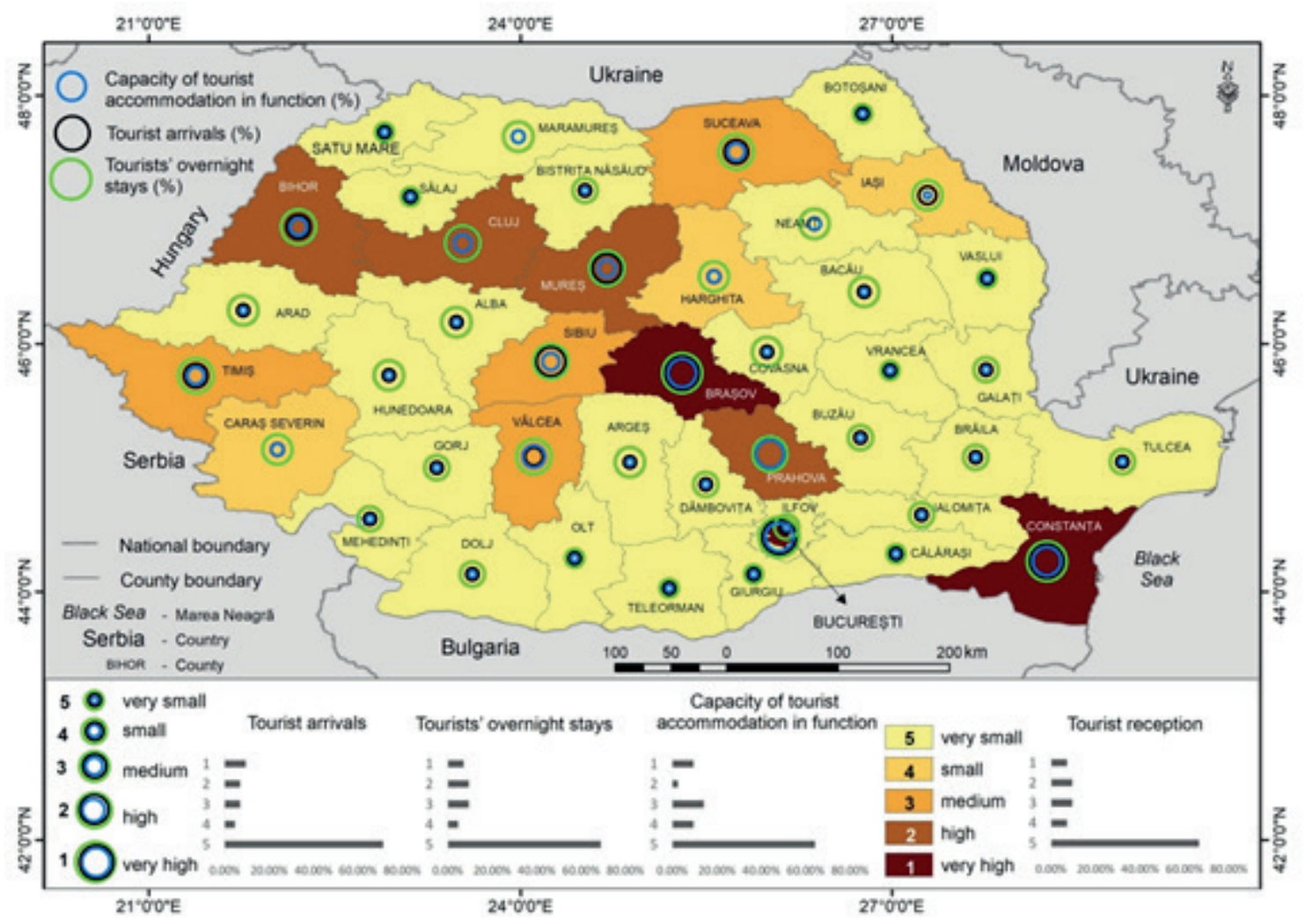

Fig. 4. Distribution of the share of the tourist reception volume at the level of counties in Romania 


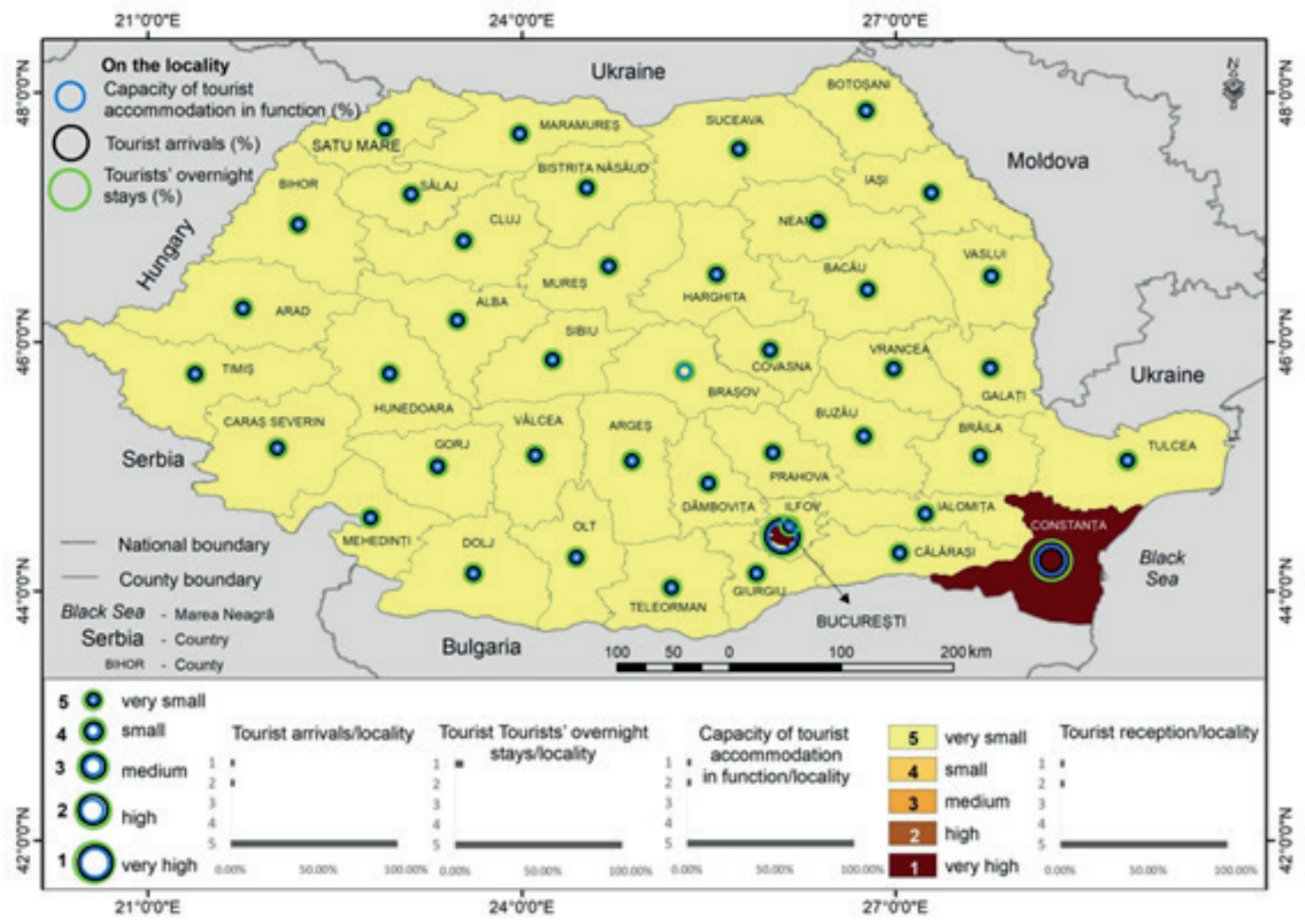

Fig. 5. Distribution of the share of the tourist reception volume relative to locality at the level of counties in Romania

Data sources: National Institute of Statistics, 2019

The analysis of the share of the volume of tourist arrivals at the level of administrative territorial units of the county type in Romania in 2018 revealed their predominance in Bucharest Municipality (16.8\%), followed in a hierarchical order by Brașov (10.3\%), Constanța (10.1\%), Cluj (5.2\%), Sibiu (4.6\%), Mureș (4.4\%), Prahova (4.3\%), Bihor (3.9\%) counties, whereas, from the assessment of spatial dispersion of tourist arrivals at counties level it emerged that the first places were occupied by Suceava (56 localities, 5.5\%), Maramureș (47 localities, 4.6\%), Harghita (46 localities, 4.5\%), Alba (45 localities, 4.4\%) and Brașov (44 localities, 4.3\%) counties (Figure 4). From the analysis of the share of the volume of tourist arrivals in localities of the counties it resulted that the highest share was held by Bucharest Municipality (83.2\%), followed by Constanța (3.1\%), Brașov (1.1\%), Prahova (0.7\%), Sibiu (0.67\%) and Cluj (0.62\%) counties (Figure 5).

The analysis of the share of the volume of tourists' overnight stays at the level of administrative territorial units of the county type in Romania revealed their predominance in Constanța county (17.4\%), followed by Bucharest Municipality (12.4\%), Brașov (9.3\%), Bihor (4.7\%), Vâlcea (4.6\%), Cluj (4.4\%) and Prahova (4.2\%), whereas, from the assessment of spatial dispersion of tourists' overnight stays at the county level it resulted that the first places were occupied by Suceava (56 localities, 5.5\%), Maramures (47 localities, 4.6\%), Harghita (46 localities, 4.5\%), Alba (45 localities, 4.4\%), Brasov (44 localities, 4.3\%) (Figure 4). From the analysis of the share of the volume of tourists' overnight stays on localities of the counties it resulted that the highest share was held by Bucharest Municipality (77\%), followed by Constanta (6.7\%), Brasov (1.3\%), Vâlcea (0.9\%), Bihor (0.87\%) and Prahova (0.86) counties (Figure 5).

The analysis of the share of the volume of accommodation capacity in function at the level of administrative territorial units of the county type in Romania in 2018 revealed 
its predominance in Constanța (11.9\%), Brașov (11.3\%), Bucharest Municipality (8.7\%), Prahova (5.1\%), Vâlcea (4.2\%), Bihor (3.9\%), Cluj (3.7\%) and Sibiu (3.6\%), whereas, from the assessment of spatial dispersion of accommodation capacity at the level of counties, it resulted that the first places were occupied by Suceava (57 localities, 5.5\%), Maramureș (47 localities, 4.5\%), Harghita (46 localities, 4.4\%), Alba (45 localities, 4.3\%) and Brașov (44 localities, 4.2\%) (Figure 4). From the analysis of the share of the volume of accommodation capacity in function at the level of the localities of the counties it resulted that the highest share was held by Bucharest Municipality (70\%), followed by Constanța (5.9\%), Brașov (2\%), Prahova (1.2\%), Vâlcea (1\%) and Bihor (0.9\%) counties (Figure 5).

The analysis of the share of the tourist reception volume on value classes at the county level revealed that $66.6 \%$ of Romania's counties have a very small tourist reception capacity, $7.2 \%$ have a small capacity, $9.5 \%$ have a medium and high capacity, whereas, only $7.2 \%$ have a very high capacity (Bucharest Municipality). A relatively similar situation, with some oscillations in terms of the value of share, also emerges from the analysis of the tourist arrivals and tourist accommodation and of accommodation capacity in function (Figure 4). A similar situation regarding the value of the share with some oscillation emerges from the analysis of the value classes of tourist arrivals, tourists' overnight stays and accommodation capacity as well (Figure 4).

The analysis of the share of the volume of tourist reception at the level of localities in 2018 revealed its predominance in Bucharest Municipality (12.6\%), followed by Constanța (5.1\%), Brașov (4.4\%), Mangalia (4\%), Cluj Napoca (3.1), Sibiu (2.5\%), Timișoara $(2.4 \%)$, Sinaia (2.18\%), Băile Felix - Băile 1 Mai (2.14\%), Eforie Nord (2.12\%), Iași (1.87\%), Predeal (1.81\%), Călimănești (1.6\%) and Oradea (1.5\%) localities (Figure 6).

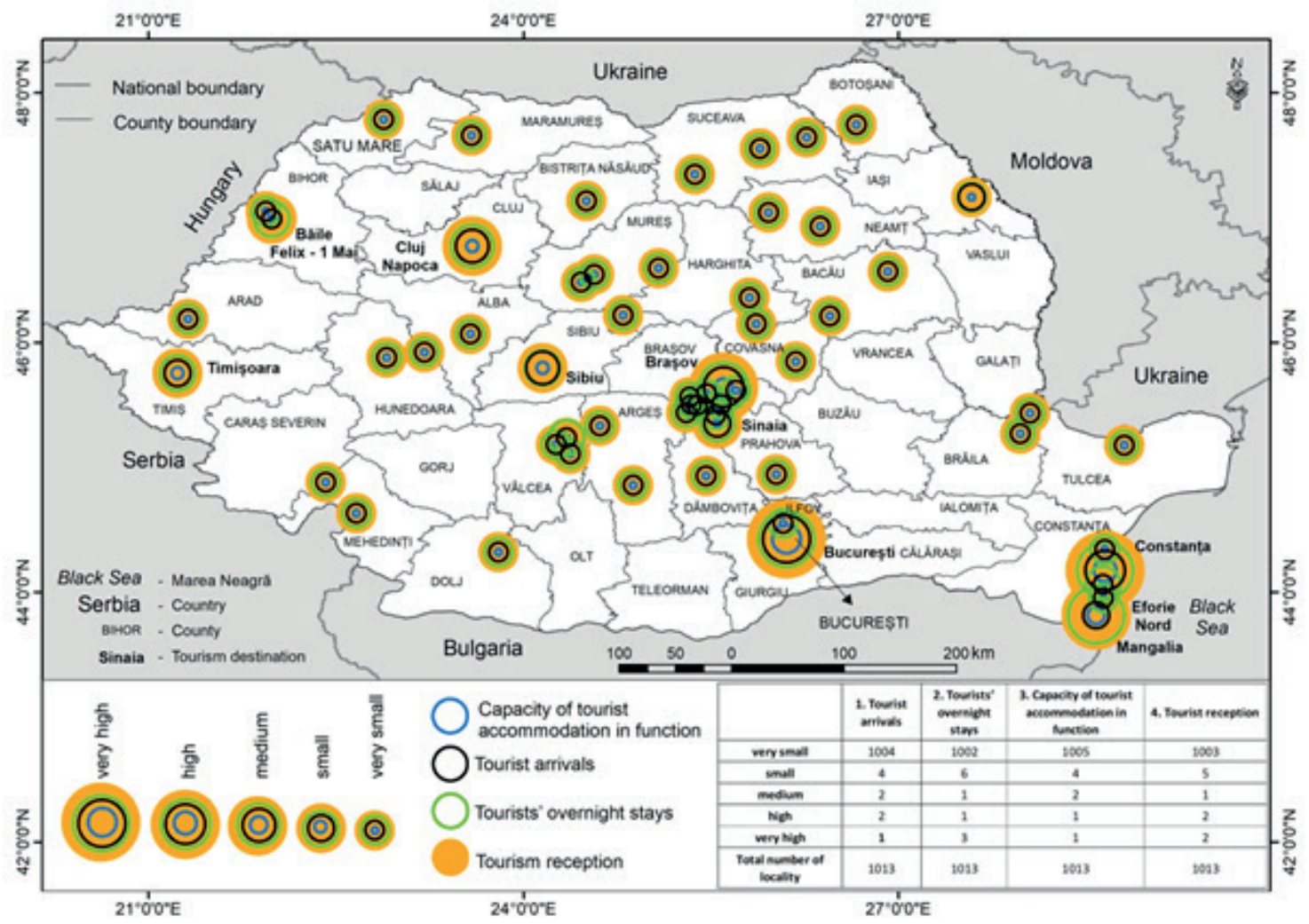

Fig. 6. Distribution of the share of the tourist reception volume at the level of localities in Romania

Data sources: National Institute of Statistics, 2019) 
The analysis of the share of the tourist reception volume in value classes at the locality level revealed that $99 \%$ (1,003 localities) of Romanian localities have very small tourist reception capacity, 0.4\% (Sibiu, Timișoara, Sinaia, Băile Felix - Băile 1 Mai și Eforie Nord) have a small capacity, 0.09\% (Cluj Napoca) have a medium capacity, whereas only $0.19 \%$ have a high capacity (Brașov and Mangalia) and $2.4 \%$ very high (București, Constanța). A similar situation regarding the value of the share with some oscillation reveals from the analysis of the value classes of tourist arrivals, tourists' overnight stays and accommodation capacity at the locality level as well (Figure 6).

\section{EMITTER TOURIST AREAS FROM ROMANIA}

Key elements with roles and important functions in the spatial dynamics of tourism have been represented. In order to identify and hierarchize the tourist emitter areas from Romania, the number and the share of travel agencies have been analyzed as well as the number and share of the localities and the related population in which the tourism agencies are based. The population was analyzed in terms of it being a potential beneficiary of tourism products, while tourism agencies were analyzed from the perspective of the roles and functions performed. In order to outline the tourist emitter centers, an analysis of the above-mentioned indicators was made at four levels of approach: at the level of Romania; at the level of development regions; at the level of the counties and at the level of the localities, viewed as basic cells in the shaping of tourist emitter areas.

In 2018, in Romania there were 1,799 travel agencies distributed unequally in 8 development regions, 42 administrative territorial units and 185 localities.

The analysis of the share of the tourist emitter volume at the level of development regions in Romania in 2018, revealed its predominance in the Bucharest Region (28.5\%), followed in a hierarchical order by the North-East Region (12.05\%), the North-West Region (11.55\%), the Central Region (11.55\%), the South Region (11.2\%), the South-East Region $(11.1 \%)$, the West Region (7.95\%), the South-West Region (6.05\%). The Bucharest Region is the most important region as a tourist emitter, emitting $28.5 \%$ of the total volume of tourist flows from Romania. It concentrates $35.2 \%$ of the total number of the travel agencies in Romania (635 units), distributed in 21 localities (11.3\% of the total numbers of the localities where travel agencies in Romania are based), which represents an average value of 30.2 travel agencies per locality. North-East Region represents the second tourist emitter region, emitting $12.05 \%$ of the total volume of tourist flows from Romania. It concentrates $9.7 \%$ of the total number of the travel agencies in Romania (173 units), distributed in 24 localities $(13 \%$ of the total numbers of the localities where travel agencies in Romania are based), which represents an average value of 7.2 travel agencies per locality. The third place is held by the North-West Region and the Central Region with a total of tourist volume flows of $23.1 \%$, respectively $11.55 \%$ each region, whereas, the last place was occupied by the South-West Region (6.05\%). This sums up $10.1 \%$ of the total number of the travel agencies in Romania (179 units), distributed in 34 localities (18.3\% of the total numbers of the localities where travel agencies in Romania are based), which represents an average value of de 5.2 travel agencies per locality (Figure 7). From the assessment of the spatial dispersion of tourist emitters, hierarchically the situation was as follows: the South Region (18.3\%), followed by the Central Region (16.3\%), the North-East Region (13\%), the South-East Region (12.4\%), Bucharest (11.3\%), the West Region (11.3\%), the North-West Region (10.3\%) and the South-West Region (7.1\%), whereas, from the analysis of the share of the tourist emitter capacity volume in the localities of the development regions, the situation is as follows: Bucharest (55.7\%), the North-West Region (3.9\%), the North-East Region (3.5\%), the South-East Region (18.4\%), the South-West Region (4.9\%), the Central Region (6\%), the West Region (4\%) and the South Region (3.6\%) (Figure 7). 


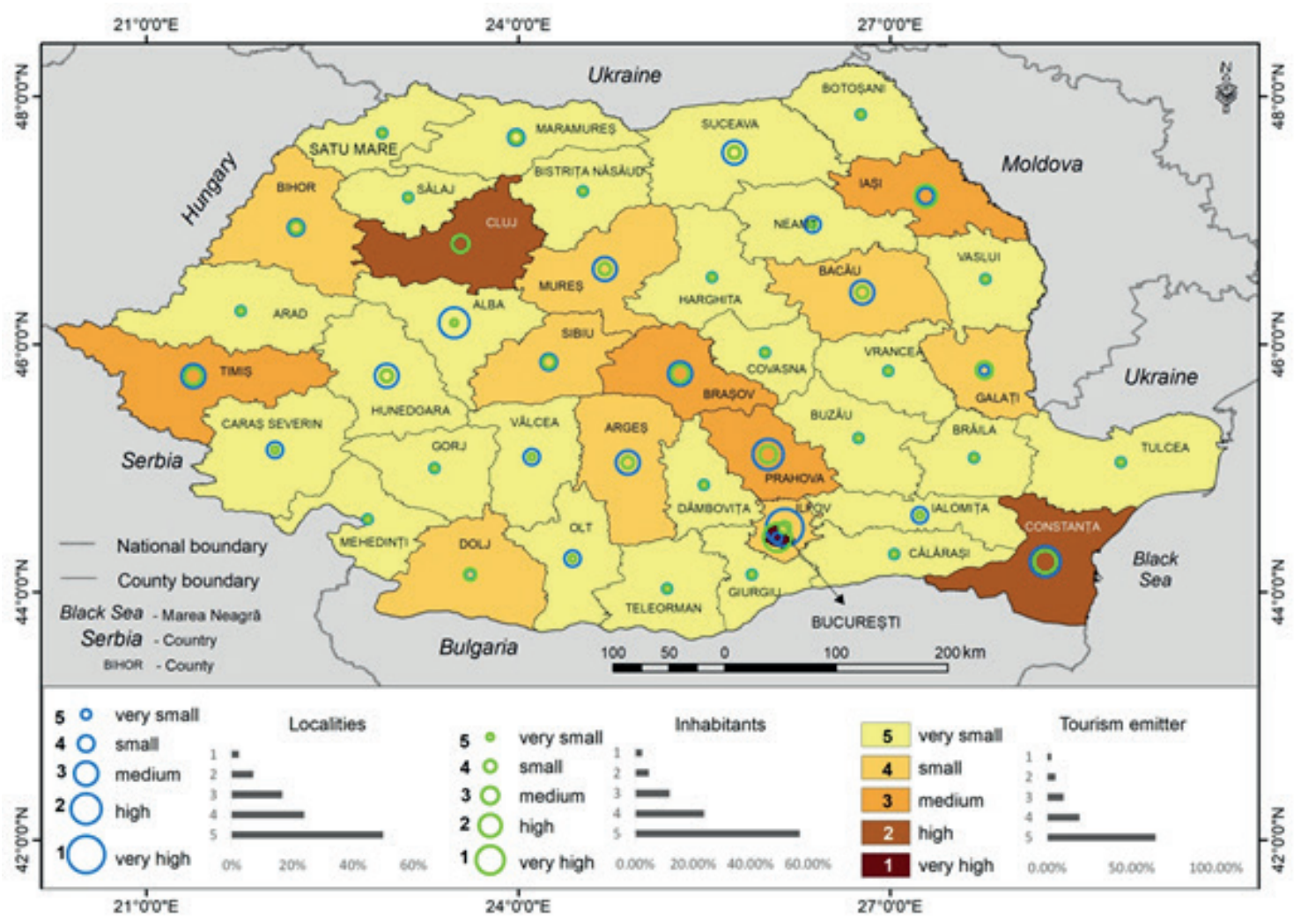

Fig. 7. Distribution of the share of the volume of the tourist emitter in development regions

Data sources: National Institute of Statistics, 2019; Ministry of Tourism, 2019

The analysis of the proportion of travel agencies in development regions in Romania in 2018 revealed their predominance in Bucharest (35.2\%), hierarchically followed by the Central Region (11.8\%), the North-West Region (11.6\%), the South-East Region (10.2\%), the South Region (10.1\%), the North-East Region (9.7\%), the West Region (6.8\%) and the SouthWest Region (4.6\%) (Figure 7). Following the assessment of the spatial dispersion of travel agencies in Romania at the level of development regions, the predominance of the South Region was revealed (34 localities, 18.3\%), followed by the Central Region (30 localities, $16.3 \%$ ), the North-East Region (24 localities, 13\%), the South-East Region (23 localities, 12.4\%), the West Region (21 localities, 11.3\%), Bucharest (21 localities, 11.3\%), the NorthWest Region (19 localities, 10.3\%) and the South-West Region (13 localities, 7.1\%), whereas, from the analysis of the proportion of travel agencies in locality at the level of development regions, the Bucharest Region stands out (30.2 travel agencies per locality, 37.4\%), followed by the North-West Region (10.9 travel agencies per locality, 13.5), the South-East Region (8 travel agencies per locality, 9.9\%), the North-East Region (7.2 travel agencies per locality, 8.9\%), the Central Region (7.1 travel agencies per locality, 7.9\%), the South-West Region (6.4 travel agencies per locality, 7.9\%), the West Region (5.8 travel agencies per locality, 7.2\%), the South Region (5.2 travel agencies per locality, 6.4\%) (Figure 7).

The analysis of the total number of the population from the localities where travel agencies are based viewed from the perspective of their ability to benefit from the services of travel agencies, at the level of the development regions in Romania, in 2018, the predominance of the Bucharest Region was revealed (21.9\%), followed by the North-East Region $(14.4 \%)$, the South Region (12.3\%), the South-East Region (12\%), the North-West Region $(11.5 \%)$, the Central Region (11.3\%), the West Region (9.1\%) and the South-West Region (7.5\%) (Figure 7). Following the assessment of the spatial dispersion of the population from the localities where travel agencies are based, at the level of development regions, the predominance of Bucharest was shown $(2,387,570$ inhabitants, $21.9 \%)$, followed by the North-East Region (1,568,053 inhabitants, $14.4 \%)$, the South Region $(1,346,338$ inhabitants, 
12.3\%), the South- the East Region (1,301,035 inhabitants, 12\%), the North-West Region $(1,255,761$ inhabitants, $11.5 \%)$, the Central Region (1,236,823 inhabitants, $11.3 \%)$, the West Region (997,608 inhabitants, 9.1\%) and the South-West Region (823,980 inhabitants, 7.5\%), whilst, from the analysis of the share of population in locality at the level of development region, the Bucharest Region stands out (113,693 inhabitants per locality, 23\%), followed by the North-West Region (66,092.6 inhabitants per locality, 13.4\%), the North-East Region $(65,335.5$ inhabitants per locality, 13.2\%), the South-West Region (63,383 inhabitants per locality, 12.8\%), the South-East Region (56,566.7 inhabitants per locality, 11.5\%), the West Region (47,505.1 inhabitants per locality, 9.6\%), the Central Region (41,227.4 inhabitants per locality, 8.4\%), the South Region (39,598.1 inhabitants per locality, 6.4\%) (Figure 7).

The analysis of the share of the tourist volume emitter in counties in 2018 revealed the predominance of Bucharest Municipality (26.3\%), followed by Constanța (4.8\%), Cluj (4.75\%), Brașov (3.93\%), Iași (3.91\%), Timiș (3.64\%), Prahova (3.4\%), Argeș (2.9\%) and Bihor (2.6\%) counties. In the last places regarding the share of the tourist volume emitter were Harghita (0.6\%), Sălaj (0.5\%) and Giurgiu (0.3\%) counties. Bucharest Municipality is the most important administrative territorial unit of tourist volume emitter, emitting $26.3 \%$ of the total volume of tourist flows from Romania. It concentrates $33.2 \%$ of the total number of travel agencies in Romania (598 units), distributed in one locality, which represents a share of the average value of $67.6 \%$ travel agencies per locality. Constanța County is the second administrative territorial unit of tourist emitter, emitting $4.8 \%$ of the total volume of the tourist flows. It concentrates $4.8 \%$ of the total number of the travel agencies in Romania (87 units), distributed in 12 localities (6.4\% of the total numbers of the localities where travel agencies in Romania are based), which represents an average value of 7.2 travel agencies, respectively a share of the average value of $0.8 \%$. On the opposite, in the last place, Giurgiu county $(0.3 \%)$ is situated, with $0.1 \%$ of the total number of the travel agencies in Romania (3 units), distributed in Giurgiu Municipality (Figure 8).

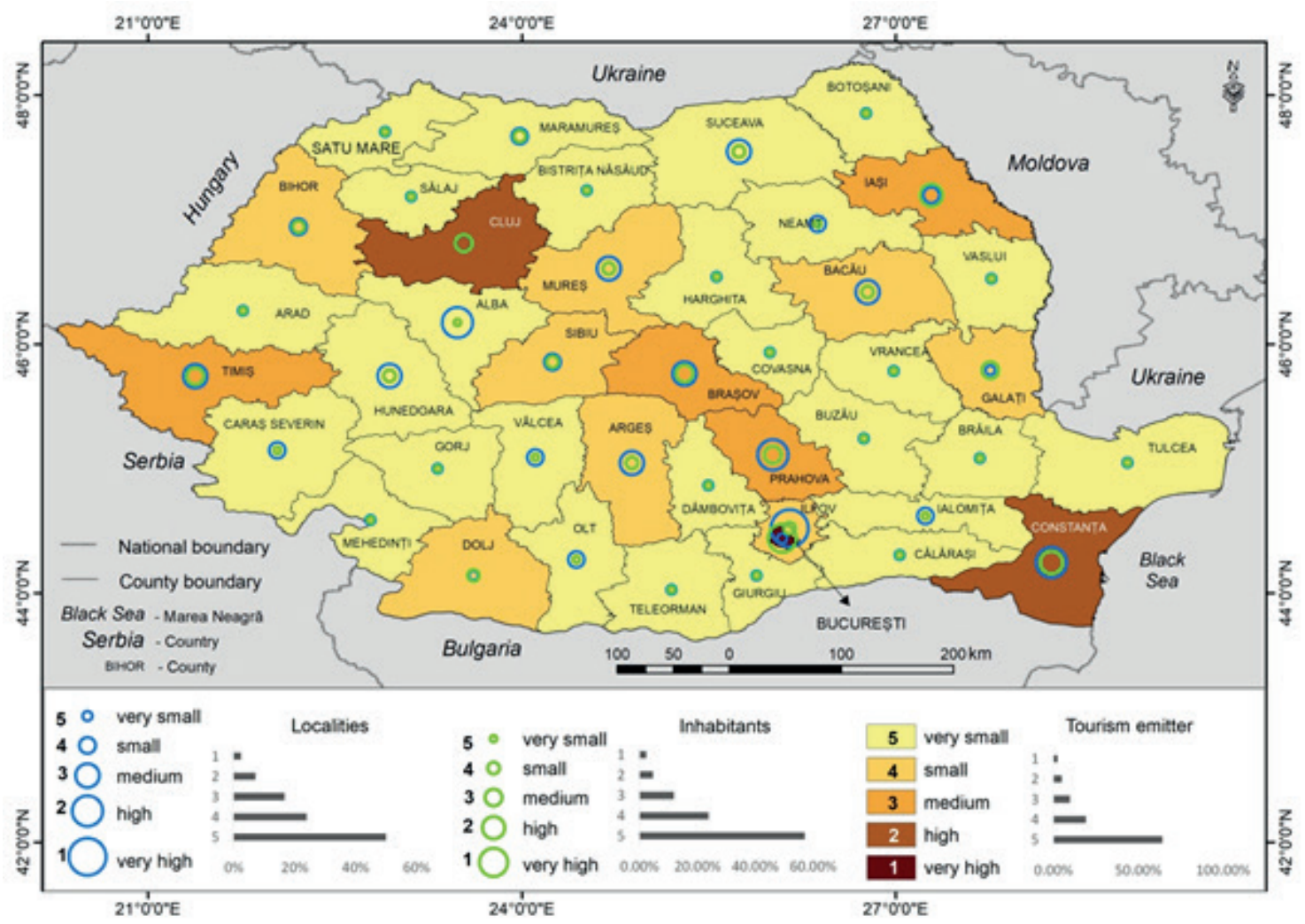

Fig. 8. Distribution of the share of the tourist emitter volume at the county level in Romania 
As regards the spatial dispersion of the tourist emitter volume, the highest share was held by Ilfov (10.8\%), Constanța (6.4\%), Prahova (6.4\%), Alba (4.3\%), Timiș (3.7) and Brasov (3.7\%) counties, whilst the analysis of the share of the tourist emitter volume in localities of the counties showed that the highest share was held by Bucharest Municipality (57.3\%), followed by Dolj (2.68\%), Iași (2.1\%), Cluj (2.08\%), Galați (2\%) and Brăila (1.8\%) counties (Figure 9).

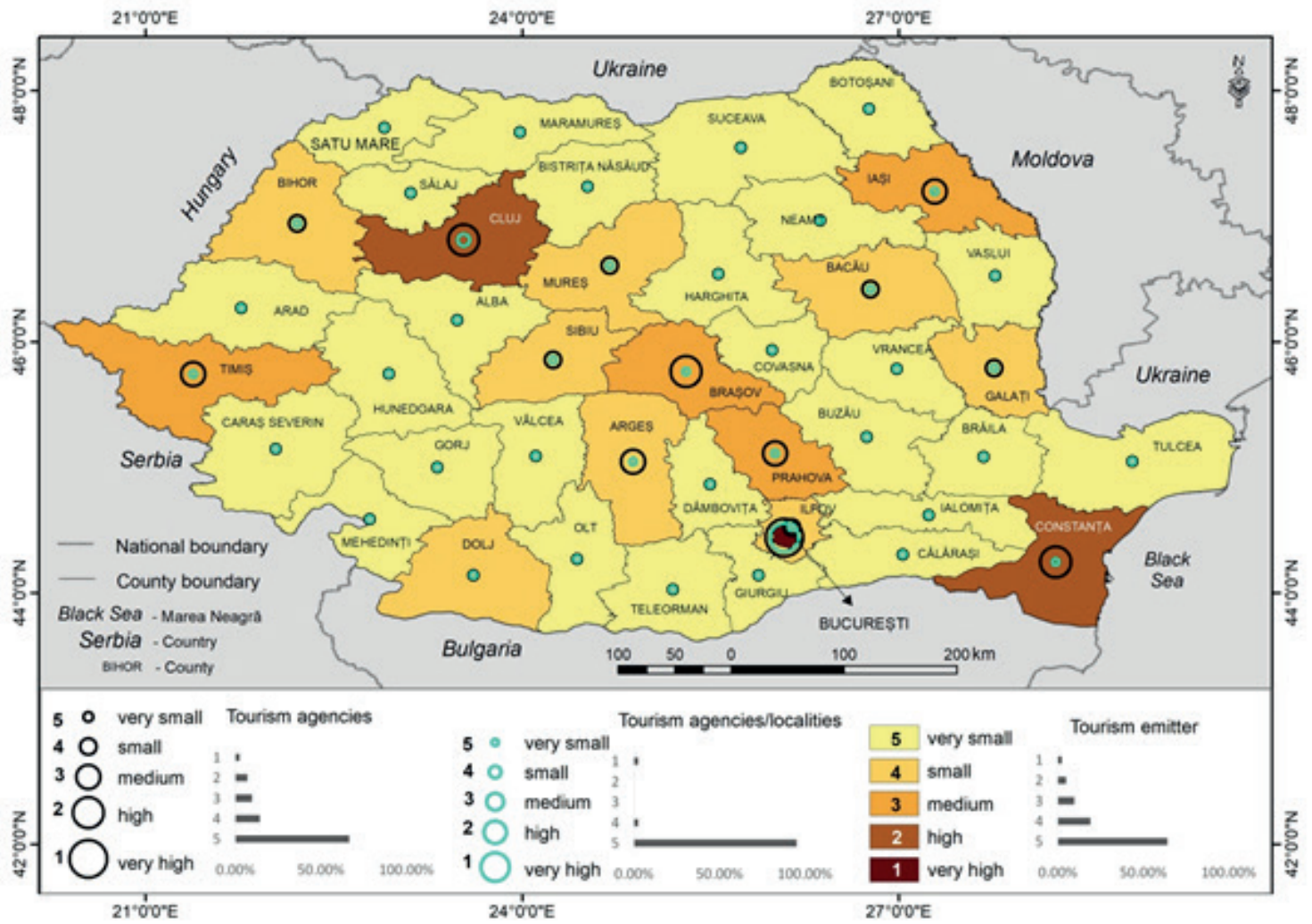

Fig. 9. Distribution of the share of the tourist emitter volume on locality at the county level in Romania

Data sources: National Institute of Statistics, 2019; Ministry of Tourism, 2019)

The analysis of the proportion of travel agencies in counties in 2018 revealed the predominance on Bucharest Municipality (33.2\%), followed by Cluj (5.5\%), Constanța (4.8\%), Brașov (4.5\%), Iași (3.6\%), Timiș (3.5\%), Prahova (3.3\%), Argeș (3.1\%), Sibiu (2.8\%) and Bihor (2.8\%) counties. In the last places regarding the share of the tourist emitter volume, Mehedinți (0.38\%), Teleorman (0.33\%) and Giurgiu (0.1\%) were situated (Figure 8). An assessment of the spatial dispersion of travel agencies revealed that the highest share was held by Ilfov (10.8\%), Constanța (6.4\%), Prahova (6.4\%), Alba (4.3\%) and Brasov (3.7\%) counties, whilst, an assessment of the share of the travel agencies on localities of the counties revealed that the highest share was held by Bucharest Municipality (67.6\%), followed by Cluj (2.2\%), Iași (1.86\%), Dolj (1.80\%), Brăila (1.5\%) and Sibiu (1.4\%) (Figure 9).

The analysis of the numerical proportion of the population in the localities where travel agencies are based at the county level in 2018 revealed the predominance of Bucharest Municipality (19.4\%), followed by Constanța (4.7\%), Iași (4.1\%), Cluj (3.9\%), Timiș (3.7\%), Prahova (3.4\%), Brașov (3.3\%) and Galați (3.2\%) counties. In the last places regarding the share of the tourist emitter volume, Harghita $(0.7 \%)$, Sălaj $(0.63 \%)$ and Giurgiu $(0.61 \%)$ counties were situated (Figure 8$)$. An assessment of the spatial dispersion of the 
population from the localities where travel agencies are based revealed that the highest share was held by Ilfov (10.8\%), Constanța (6.4\%), Prahova (6.4\%), Alba (4.3\%), Timiș (3.7) and Brasov (3.7\%) counties, whilst an assessment of the share of the population from the localities of the counties revealed that the highest share was held by Bucharest Municipality 47.1\%), followed by Dolj (3.5\%), Galați (2.6\%), Iași (2.5\%) and Brăila (2.2\%) counties (Figure 9).

The analysis of value classes of the share of tourist emitter volume at the county level revealed that $64.20 \%$ of Romania's counties have a very small emitter capacity, $19.10 \%$ have a small emitter capacity, $9.5 \%$ have a medium emitter capacity, whilst only $4.8 \%$ have a high emitter capacity (Constanța and Cluj counties) and $2.4 \%$ a very high capacity (Bucharest Municipality). A similar situation with some oscillations regarding the value of the share is revealed as well from the analysis of value classes of the share of travel agencies and population of the localities where the travel agencies are based for each county (Figures 8, 9).

The analysis of the share of the tourist emitter volume in localities in 2018 revealed the predominance on Bucharest Municipality (26.3\%), followed by Cluj Napoca (3.9\%), Iași (3.3\%), Brasov (3.29\%), Constanța (3.24\%), Timișoara (2.9\%), Oradea (2.32\%), Galați (2.3\%), Craiova (2.2\%), Ploiești (2.1\%), Pitești (1.8\%) and Sibiu (1.7\%) localities (Figure 10).

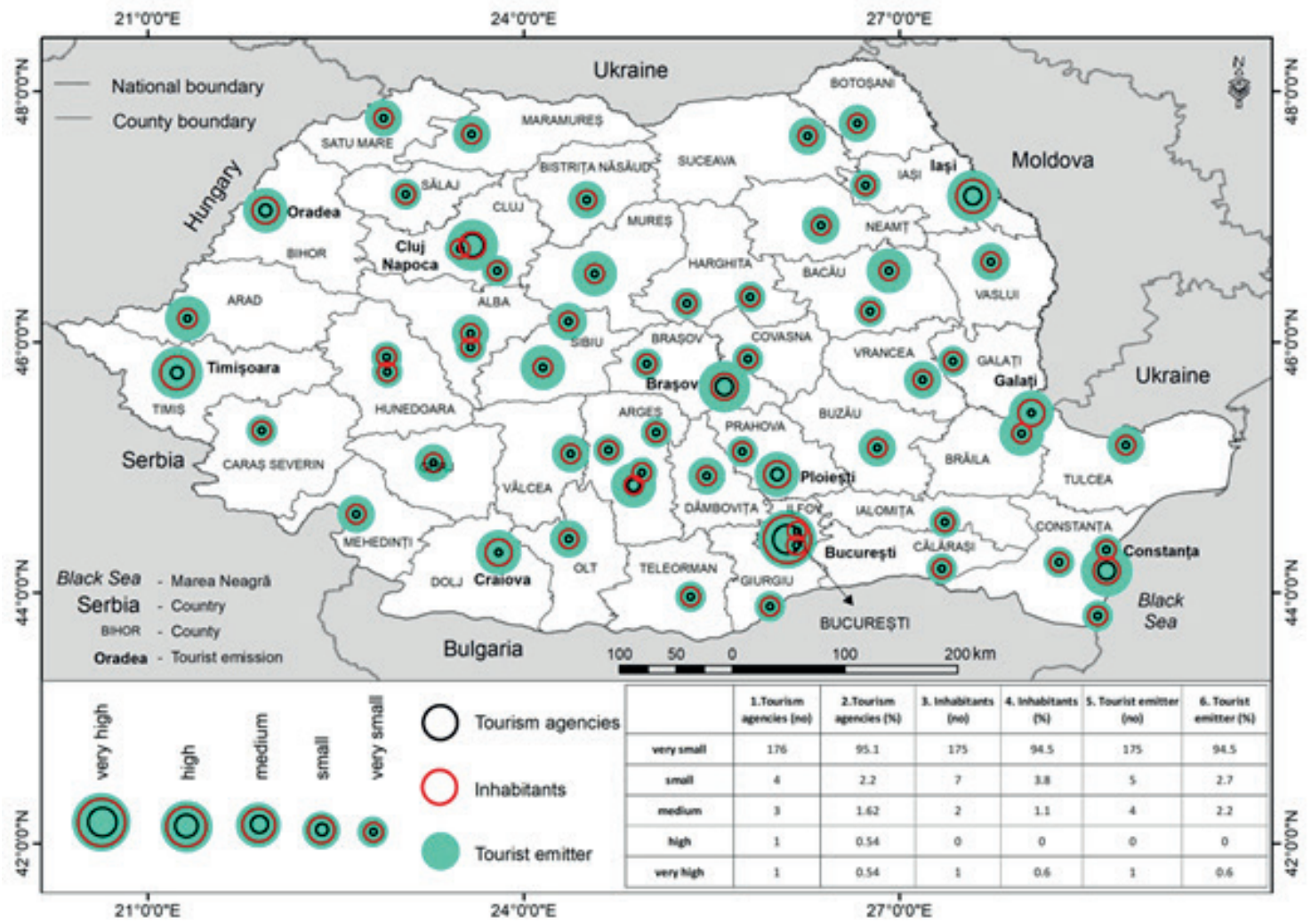

Fig. 10. Distribution of the share of the tourist emitter volume at the county level in Romania

Data sources: National Institute of Statistics, 2019; Ministry of Tourism, 2019

The analysis of the total number of the population of the localities where travel agencies are based revealed the predominance on Bucharest Municipality (19.4\%), followed by Iași (3.4\%), Timisoara (3\%), Cluj Napoca (2.9\%), Constanța (2.8\%), Galati (2.77\%), Craiova (2.76\%), Brașov (2.65\%), Ploiesti (2.09\%), Oradea (2.02\%), Brăila (1.86\%), Bacău (1.80\%), Arad (1.6\%), Pitești (1.59\%) and Sibiu counties (1.54\%) (Figure 10). 
The analysis of value classes of the share of the tourist emitter volume at the county level revealed that $64.20 \%$ of Romania's localities have a very small emitter capacity, $19.10 \%$ have a small emitter capacity, 9.5\% have a medium emitter capacity, whilst only $4.8 \%$ have a high emitter capacity (Constanța and Cluj localities) and $2.4 \%$ a very high emitter capacity (Bucharest Municipality). A similar situation with some oscillations regarding the value of the share reveals from the value classes analyses of the share of the travel agencies, the analysis of the travel agencies related to the number of the localities, the analysis of the number of the localities were travel agencies are based for each county (Figure 10).

\section{DISCUSSION}

The analysis of the capacity of the tourist emitter / reception centers indicates a high concentration of the emitter capacity ( $52.1 \%$ of the total volume of the tourist, at the level of the first 10 centers), compared with the reception capacity which is the most dispersed ( $47.8 \%$ of the total volume of tourist reception is concentrated in the first 10 centers).

The analysis of the spatial distribution of the tourist emitter centers indicates the existence of a relatively uniform distribution at the level of development regions, so that each region is represented by at least one tourist emitter center ranked in the list (top 10). From the distribution of the tourist emitter centers at the county level, a situation similar to that existent at the level of development regions emerges, with each county being represented in terms of tourist emitter at least at the level of the municipality (Figure 11).

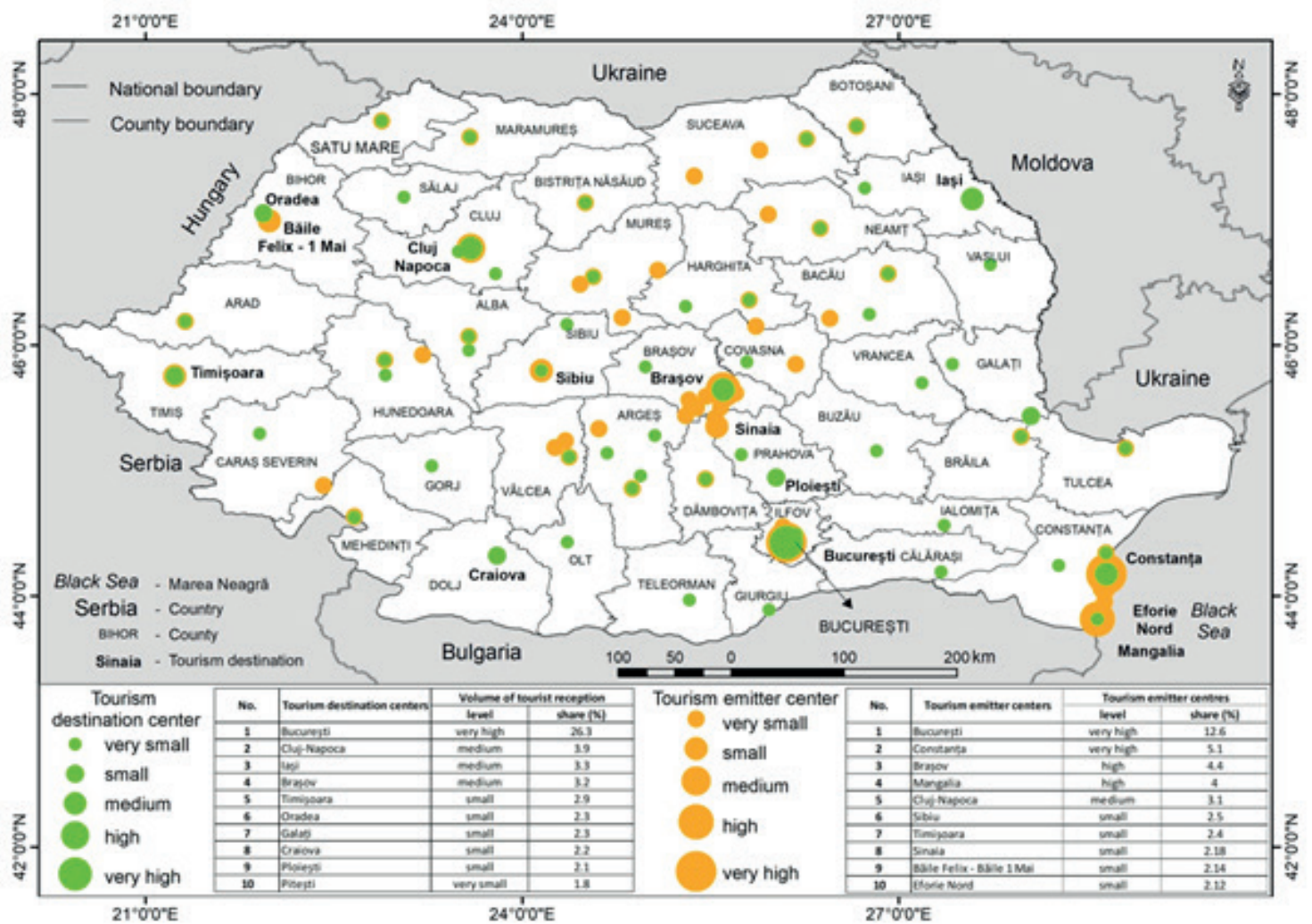

Fig. 11. Spatial distribution of the tourist emitter-reception centers from Romania

Data sources: National Institute of Statistics, 2019; Ministry of Tourism, 2019 
The analysis of the spatial distribution of the tourist centers shows a non-uniform distribution at the level of the development regions and at the level of the counties such as Gorj, Olt, Teleorman, Giurgiu, Călărași, Ialomița, Buzău, Vrancea, Vaslui și Sălaj, but they are not represented by large tourist destinations, while other counties have real agglomerations of tourist destination centers (Braşov, Constanţa, Mureş Vâlcea și Suceava) (Figure 11).

Bucharest Municipality is the most important emitter center (26.3\% of the total emitter capacity at national level) and tourist destination (12.6\% of the total capacity of tourist reception at national level). Tourist emitter is realized by the major urban centers (ClujNapoca, Iași, Brașov, Timișoara, Oradea, Galați, Craiova, Ploiești, Pitești), whilst tourist destinations are represented by both the major urban centers and some famous resorts: Mangalia, Sinaia, Băile-Felix - Băile 1 Mai and Eforie Nord (Figure 11).

The analysis of the tourist emitter and destination centers in relation to one another showed some spatial uniformity in terms of emitter centers, whilst the analysis of the tourist destination centers highlights the existence of some concentrations of which two are defining for Romanian tourism, namely the concentration on Prahova valley focused on mountain tourism and winter sports and on the Romanian Black Sea focused on sun and sea tourism.

\section{CONCLUSIONS}

In the last period, the accentuated globalization that humanity is facing currently has made tourism to be the main purpose of population migration. This is also felt in the data on the tourist infrastructure, accommodation capacity, number of tourist arrivals and overnight stays in Romania, which are on a continuous ascending slope since 2008 and until now. Taking into account this phenomenon, the importance of a study regarding the analysis and ranking of the tourist emission and reception centers in Romania is even greater. However, identifying and explaining spatial relationships from the emitter centers and tourist destination is a delicate operation implying many unknown factors. However, we tried to capture some defining aspects in the shaping of the spatial relationships from the two categories of centers (capacity of tourist emitter/reception, localization on development regions and counties level and their location relation to each other. The analyses carried out thus highlighted the fact that tourist flows are concentrated in areas with rich natural resources (mountains, sea or thermal waters) and in areas of large cities (especially the country's capital - Bucharest), while areas that do not have special natural resources or large cities register few tourists. At the same time, the big cities of Romania stand out as the main tourist emitter centers. This being said and considering the strong tourist vocation of this country, based on the natural beauty and cultural richness, Romanian tourism has all the prerequisites to grow and to individualize as one of the main engines of the economy.

\section{REFERENCES}

[1] Marcu V, Buhaș S. Sport organisations - management and science, Procedia - Social and Behavioral Sciences. 2014;117,678-682. https://doi.org/10.1016/j.sbspro.2014.02.281

[2] Dragoș P, Lucaciu G, Trifa I, Ștef Gavriș M, Szabo-Alexi P, Buhaș S. Aspects regarding the influence of communication on the motivation of employees in some sports organisations. In Proceedings of the 4th international conference of the universitaria consortium (ICU 2018): The impact of sport and physical education science on today society, Editografica SRL, INTL Proceedings Div, Bologna, Italy. 2018;73-77.

[3] Dragoș P, Lucaciu G, Diniș I, Ștef Gavriș M, Szabo-Alexi P, Buhaș S. Concepts concerning the content of children's training in some sport games Proceedings of the 4th international conference of the universitaria consortium (ICU 2018): The impact of sport and physical education science on today society, Editografica SRL, INTL Proceedings Div, Bologna, Italy. 2018;62-72.

[4] Cuvelier P. Anciennes et nouvelles formes de tourisme: une approche socio-économique. Editions L'Harmattan; 1998.

[5] Hall CM. Space-time accessibility and the tourist area cycle of evolution: The role of geographies of spatial interaction and mobility in contributing to an improved understanding of tourism. In: Butler R, editor. The Tourism Area LifeCycle, Clevedon: Channelview, forthcoming; 2004. 
[6] Hall CM, Müller D. Tourism, Mobility and Second Homes: Between Elite Landscape and Common Ground, Clevedon: Channelview Publications, forthcoming; 2004. https://doi.org/10.21832/9781873150825

[7] Williams AM, Hall CM. Tourism and migration: new relationships between production and consumption. Tourism geographies. 2000;2(1):5-27. https://doi.org/10.1080/146166800363420

[8] Williams AM, Hall CM. Tourism, migration, circulation and mobility. In: Tourism and migration. Springer, Dordrecht; 2002, 1-52.

[9] Williams AM, King R, Warnes A, Patterson G. Tourism and international retirement migration: new forms of an old relationship in southern Europe. Tourism Geographies. 2000; 2(1):28-49. https://doi.org/10.1080/146166800363439

[10] Tremblay R. Miami. Sage International Encyclopedia of Travel and Tourism. Thousand Oaks, CA: Sage Publications; 2017. https://doi.org/10.4135/9781483368924.n479

[11] Tremblay R, Dehoorne O. Entre tourisme et migration. Paris: L'Harmattan; 2018.

[12] Hall CM, Williams A. Tourism and Migration: New Relationships between Production and Consumption, Dordrecht: Kluwer; 2002.

[13] O'Reilly K. When is a tourist? The articulation of tourism and migration in Spain's Costa del Sol. Tourist studies. 2003;3(3):301-317. https://doi.org/10.1177/1468797603049661

[14] Casado-Díaz MA, Casado-Díaz AB, Casado-Díaz JM. Linking tourism, retirement migration and social capital. Tourism Geographies. 2014;16(1):124-140. https://doi.org/10.1080/14616688.2013.851266

[15] Leitão NC, Shahbaz M. Migration and tourism demand. Theoretical and Applied Economics. 2012; 39-48.

[16] Rodriguez V. Tourism as a recruiting post for retirement migration. Tourism Geographies. 2001;3(1):52-63. https:// doi.org/10.1080/14616680010008702

[17] Gössling S, Schulz U. Tourism-related migration in Zanzibar, Tanzania. Tourism Geographies. 2005;7(1):43-62. https:// doi.org/10.1080/1461668042000324058

[18] Price MF, Moss LA, Williams PW. Tourism and amenity migration. Mountains of the world: A global priority. 1997; 249-280.

[19] Böröcz J. Leisure migration: a sociological study on tourism. Pergamon Press; 1996.

[20] UNWTO. Tourism Highlights, 2018 Edition, World Tourism Organization; 2018.

[21] Herman GV, Peptenatu D, Grama V, Pintilii RD. Tourism and Local Development. Study Case: Băile Felix-Băile 1 Mai Tourism System, Bihor County, Romania. Analele Universitatii din Oradea, Seria Geografie. 2018;28(1):131-7.

[22] Wendt J, Buhas R, Herman GV. Experience of the Baile-Felix Tourist System (Romania) For the Protection and Promotion of the Grey Seal as a Brend on the Hel Peninsular (Poland). Baltic Region/Baltijskij Region. 2019;11(1):109116. https://doi.org/10.5922/2079-8555-2019-1-8

[23] Ilies DC, Baias S, Buhas R, et al. Environmental education in protected areas. Case study from Bihor County, Romania. GeoJournal of Tourism and Geosites. 2017;19(1):126-32.

[24] Ilieș DC, Herman G, Ilieș A, et al. Tourism and Biodiversity in Natura 2000 Sites. Case Study: Natura 2000 Valea Roșie (Red Valley) Site, Bihor County, Romania. Études caribéennes. 2017;(37-38). https://doi.org/10.4000/ etudescaribeennes.11262

[25] Ilieș DC, Buhaș R, Ilieș M, et al. Sport activities and leisure in Nature 2000 Protected Area - Red Valley, Romania, J Environ Protect Ecology. 2018;19(1):367-72.

[26] Tremblay R, O'Reilly K. La mise en tourisme des communautés transnationales: Le cas des Britanniques en Espagne et Québécois en Floride. Tourism Review. 2004;59(3): 20-23. https://doi.org/10.1108/eb058438

[27] Ilieş A, Ilieş DC, Tătar C, Ilieş M. Geography of Tourism in Romania. In the Geography of Tourism of Central and Eastern European Countries (pp. 329-374). Springer, Cham; 2017. https://doi.org/10.1007/978-3-319-42205-3 9

[28] Ilieș DC, Oneț A, Marcu FM, et al. Investigations on Air Quality in the Historic Wooden Church in Oradea City, Romania. Environ Eng Management J (EEMJ). 2018;17(11):2731-39. https://doi.org/10.30638/eemj.2018.272

[29] IIies DC, Onet A, Wendt JA, et al. Study on microbial and fungal contamination of air and wooden surfaces inside of a historical Church from Romania. J Environ Biol. 2018;39(6):980-4. https://doi.org/10.22438/jeb/39/6/MRN-658

[30] Indrie L, Oana D, Ilieş M, et al. Indoor air quality of museums and conservation of textiles art works. Case study: Salacea Museum House, Romania. Industria Textila. 2019;70(1):88-93. https://doi.org/10.35530/IT.070.01.1608

[31] Catudan JMJ. The Impact of Tourist Arrivals, Physical Infrastructures, and Employment, on Regional Output Growth Procedia-Social and Behavioral Sciences. 2016;(31)219:175-84. https://doi.org/10.1016/j.sbspro.2016.05.003

[32] National Institute of Statistics. 2019 [Available at http://statistici.insse.ro:8077/tempo-online/\#/pages/tables/inssetable] [Accessed on June, 2019].

[33] Ministry of Tourism. 2019 [Available at http://turism.gov.ro/web/autorizare-turism/, http://turism.gov.ro/web/ wp-content/uploads/2019/05/LISTA-AGENTIILOR-DE-TURISM-LICEN\%C8\%9AIATE-ORGANIZATOARE-SIINTERMEDIARE-actualizare-10.05.2019.xlsx] [Accessed on July, 2019].

[34] Herman GV, Gaceu O, Mester C, Baias S, Caciora T, Wendt JA. Spatial Analysis of Water Quality in Natura 2000 Sites Bihor, Romania. J Environ Protect Ecology. 2019;20(4):2121-29.

[35] Ilies A, Wendt JA, Ilies DC, et al. The patrimony of wooden churches, built between 1531 and 2015 , in the Land of Maramureș, Romania. Journal of Maps. 2016;12(sup1):597-602. https://doi.org/10.1080/17445647.2016.1243075

[36] Ilieș DC, Oneț A, Herman G, et al. Exploring the Indoor Environment of Heritage Buildings and its Role in the Conservation of Valuable Objects. Environ Eng Management J. 2019;18(12):2579-86. https://doi.org/10.30638/ eemj.2019.243

[37] Romocea T, Onet A, Sabău NC, Onet C, Herman GV, Pantea E. Change of the Groundwater Quality from Industrial Area Oradea, Romania, Using Geographic Information Systems (GIS). Environ Eng Management J (EEMJ). 2018;17(9):218999. https://doi.org/10.30638/eemj.2018.217

[38] Bramo F. The role of railway infrastructure on the tourism development (case Albania). Alban J Agricult Sci. 2013;12(2):297-300. 
[39] Kapera I. Sustainable tourism development efforts by local governments in Poland. Sustainable cities and society. 2018;40:581-8. https://doi.org/10.1016/j.scs.2018.05.001

[40] Herman GV, Caciora T, Dumbravă R, et al. Geographical considerations regarding the tourist information and promotion centers from Bihor county, Romania. GeoJournal of Tourism and Geosites. 2019c;27(4):1439-1448. https:// doi.org/10.30892/gtg.27427-446

[41] Herman GV, Ilies DC, Dumbravă R, Wendt J, Ilies A. Methodological Aspects Regarding the Quantification of the Role Of Tourism Promotion Centers in Creating the Destination Image in Romania. Études caribéennes. 2019;(43-44). https://doi.org/10.4000/etudescaribeennes.16642

[42] Herman GV, Wendt AJ, Dumbravă R, Gozner M. The role and importance of promotion centers in creating the image of tourist destination: Romania. Geographia Polonica. 2019;92(4):443-54. https://doi.org/10.7163/GPol.0158

[43] Lindner-Cendrowska K. Assessment of bioclimatic conditions in cities for tourism and recreational purposes (a Warsaw case study). Geographia Polonica. 2013;86(1):55-66. https://doi.org/10.7163/GPol.2013.7

[44] San Martín H, Herrero A, García de los Salmones MD. An integrative model of destination brand equity and tourist satisfaction. Current Issues in Tourism. 2019 Oct 2;22(16):1992-2013. https://doi.org/10.1080/13683500.2018.14 28286

[45] Toral SL, Martínez-Torres MR, Gonzalez-Rodriguez MR. Identification of the Unique Attributes of Tourist Destinations from Online Reviews. Journal of Travel Research. 2018;57(7):908-19. https://doi.org/10.1177/0047287517724918

[46] Herman GV, Grama V, Sonko SM, et al. Online Information Premise in the Development of Bihor Tourist Destination, Romania. Folia Geographica. 2020;62(1).

[47] Mendola D, Volo S. Building composite indicators in tourism studies: Measurements and applications in tourism destination competitiveness. Tourism Management. 2017;59:541-53. https://doi.org/10.1016/j.tourman.2016.08.011

[48] Sainaghi R, Phillips P, Zavarrone E. Performance measurement in tourism firms: A content analytical meta-approach. Tourism Management. 2017;59:36-56. https://doi.org/10.1016/j.tourman.2016.07.002

[49] Gómez-Vega M, Picazo-Tadeo AJ. Ranking world tourist destinations with a composite indicator of competitiveness: To weigh or not to weigh?. Tourism Management. 2019;72:281-91. https://doi.org/10.1016/j.tourman.2018.11.006

[50] Mariani M M, Buhalis D, Longhi C, Vitouladiti O. Managing change in tourism destinations: Key issues and current trends. Journal of Destination Marketing \& Management. 2014;2(4):269-72. https://doi.org/10.1016/j. jdmm.2013.11.003 